\title{
LOGICZNE MYŚLENIE W UCZENIU SIĘ MATEMATYKI - ZADANIA OTWARTE I ZAMKNIĘTE
}

\author{
Agnieszka Borowiecka \\ Wydział Nauk Społecznych \\ Uniwersytet Humanistyczno-Przyrodniczy im. Jana Długosza w Częstochowie \\ ul. Jerzego Waszyngtona 4/8, 42-200 Częstochowa \\ e-mail: a.borowiecka@ujd.edu.pl \\ ORCID: 0000-0002-2624-907X
}

\begin{abstract}
Abstrakt
Cel badań. Celem badania było sprawdzenie poziomu logicznego myślenia uczniów, którzy ukończyli pierwszy etap edukacyjny.

Metoda badań. Wśród uczniów rozpoczynających naukę w klasie IV na terenie miasta Częstochowy i powiatu częstochowskiego przeprowadzono test $\mathrm{w}$ zakresie logicznego myślenia. Test składał się z 10 zadań zamkniętych, jednokrotnego wyboru. Zadania obejmowały treści matematyczne, praktyczne, analizę sytuacji i treści językowe. Za poprawną odpowiedź uczeń otrzymywał jeden punkt, a za złą odpowiedź lub jej brak zero punktów.

Wyniki badań. Uczniowie mają problem ze zrozumieniem treści zadania i dokonaniem jego analizy. Niejednokrotnie błędnie dobierali także metody rozwiązania zadań. Uczestnicy badania lepiej radzili sobie z rozwiązaniem zadań otwartych niż zadań zamkniętych. Poziom logicznego myślenia po zakończeniu pierwszego etapu edukacyjnego nie jest zadowalający.

Wnioski. Matematyka jako przedmiot szkolny towarzyszy uczniom na każdym etapie edukacji. Wiedza z jego zakresu jest weryfikowana już po ukończeniu pierwszego etapu nauczania podczas tzw. „trzecioteściku”, po ukończeniu szkoły podstawowej podczas egzaminów ósmoklasisty oraz po ukończeniu szkoły średniej podczas egzaminu maturalnego. $Z$ opracowanych wyników badań wynika, iż osiągnięcia matematyczne uczniów zależą od poziomu sprawności umysłowej, a głównie od umiejętności logicznego myślenia. Przeprowadzony test wykazał także, że dla większości uczniów matematyka jest wyzwaniem, wymaga bowiem rzetelności, umiejętności analizowania, dochodzenia do wniosków i przede wszystkim logicznego myślenia.
\end{abstract}

Słowa kluczowe: logiczne myślenie, myślenie matematyczne, edukacja, uczenie się matematyki, zadania zamknięte, zadania otwarte

Logical thinking in learning mathematics - open and closed tasks 


\begin{abstract}
Aim of the study. The aim of the study was to check the level of logical thinking of pupils who had completed the first stage of education.

Method. A test of logical thinking was carried out among pupils starting their education in grade IV in the city of Częstochowa and the surrounding area. The test consisted of 10 single-choice closed tasks. The tasks included mathematical and practical content, situation analysis and linguistic content. The pupil received one point for a correct answer, and zero points for a wrong answer or no answer.

Results. Pupils have trouble with understanding the content of the task and analyzing it. Frequently, they also incorrectly selected the methods of solving the tasks. The study participants were better at solving open tasks than closed tasks. The level of logical thinking after the end of the first stage of education is not satisfactory.

Conclusions. Mathematics as a school subject accompanies pupils at every stage of their education. Knowledge in its field is verified after completing the first stage of education during the so-called "third-grade test", after completing primary school during the eighth grade exams and after graduating from high school during the matriculation exams. The research results show that the mathematical achievements of pupils depend on the level of mental efficiency, and mainly on the ability to think logically. The test also showed that for most pupils, mathematics is a challenge, as it requires reliability, the ability to analyze, reach conclusions and, above all, logical thinking.

Key words: logical thinking, mathematical thinking, education, studying math, closed tasks, open tasks
\end{abstract}

\title{
WPROWADZENIE
}

Matematyka jako przedmiot szkolny towarzyszy uczniom na każdym etapie edukacji, a pozyskana wiedza weryfikowana jest po ukończeniu każdego z nich. I tak organizowany jest ",trzecioteścik" po ukończeniu III klasy szkoły podstawowej, egzamin ósmoklasisty po ukończeniu szkoły podstawowej oraz egzamin maturalny na zakończenie szkoły średniej. Podczas każdego z nich sprawdzane są wiedza i umiejętności zdobyte $\mathrm{w}$ poszczególnych klasach. $\mathrm{W}$ arkuszach egzaminacyjnych prezentowane zadania składają się zarówno z pytań zamkniętych, jak i otwartych. Termin „zadanie" jest tutaj rozumiany szeroko, ale bazując na definicji stworzonej przez amerykańskiego matematyka węgierskiego pochodzenia oraz dydaktyka matematyki Georga Pólyi (1976) stwierdzić należy, że zadanie pojawia się zawsze wtedy, kiedy zachodzi potrzeba świadomego poszukiwania środka, za pomocą którego można osiagnąć dobrze widoczny, lecz chwilowo niedostępny cel. Rozwiązanie zadania polega tym samym na szukaniu właśnie tego środka. Testy i sprawdziany szkolne prowadzone na bieżąco w każdej klasie zawierają różne zadania. Zadania zamknięte mają jasno określone dane i szukane. Podczas ich rozwiązywania uczeń nie zastanawia się, jaką metodę zastosować. Zadania typu zamkniętego pozwalają na utrwalanie elementów rozumowania, ale nie wpływają na wszechstronny rozwój uczniów oraz na swobodne myślenie. Stosowanie jedynie zadań zamkniętych utrudnia, a czasami nawet uniemożliwia dostrzeganie problemów, ich formułowanie, a także wyciaganie wniosków i weryfikowanie hipotez. Tym samym w edukacji niezbędne jest uzupełnianie zadań zamkniętych o zadania otwarte. To one umożliwiają uczniom podejmowanie dzia- 
łań różnymi sposobami i metodami, prowadzącymi do otrzymania wyniku. Podczas rozwiązywania takich zadań uczniowie nie ograniczają się jedynie do zastosowania wzorów, ale kreatywnie szukają wariantów rozwiązań i analizują dokładnie treść zadania. W zadaniach otwartych uczniowie rozwiązują problemy, które zostały sformułowane w ich treści. W zadaniach testowych formułowanie problemów nie występuje. W edukacji matematycznej niezbędne jest łączenie obu typów zadań.

Zgodnie z założeniami Georga Pólyi (1976) określone zostały etapy rozwiązywania zadań matematycznych. Pierwszym etapem jest zrozumienie problemu/zadania (patrz i myśl), następnie ułożenie planu rozwiązania (planuj), realizacja planu - rozwiązanie zadania (działaj) oraz rzut oka wstecz (spójrz wstecz, gdzie uczeń sprawdza wynik). Etapy te są współcześnie powszechnie akceptowane i stosowane przez nauczycieli i dydaktyków matematyki. Zastosowanie tych zasad jest dużo łatwiejsze w kontekście zadań otwartych, gdzie uczeń w celu ich rozwiązania musi przejść przez wszystkie elementy proponowane przez Pólyę.

\section{Myślenie w edukacji matematycznej}

Podczas rozwiązywania zadań matematycznych mamy do czynienia z myśleniem matematycznym, myśleniem logicznym, myśleniem refleksyjnym oraz myśleniem zbieżnym i rozbieżnym. Do rozwiązywania zadań otwartych niezbędne jest myślenie rozbieżne, inaczej nazywane dywergencyjnym. Polega ono na generowaniu wielu nowych informacji w oparciu o te, które są już w posiadaniu ucznia. Myślenie to cechuje się płynnością (w rozumieniu łatwości i zdolności wytwarzania w krótkim czasie dużej ilości pomysłów na rozwiązanie danego problemu), giętkością (w rozumieniu zdolności wytwarzania różnych pod względem jakościowym pomysłów) i oryginalnością (pozwala na wyjście poza stereotypowe rozwiązania problemu). W edukacji matematycznej myślenie to wykorzystywane jest do zadań związanych z koniecznością poszukiwania rozwiązania w sytuacji, w której nie ma wypracowanego schematu postępowania, który można zastosować podczas ich rozwiązywania (Gębuś, Pierzchała, 2016). Myślenie to jest zatem niezbędne do rozwiązywania zadań otwartych oraz zadań o charakterze problemowym. W kontekście nabywania kompetencji matematycznych myślenie dywergencyjne powinno wzajemnie uzupełniać się z myśleniem logicznym i myśleniem o charakterze dedukcyjnym (Bonar, 2013). W procesie uczenia się matematyki istotną rolę odgrywa również myślenie refleksyjne. Składa się ono z elementów, które mogą wprowadzać ucznia w stan zakłopotania, niepewności, zaniepokojenia, zwątpienia, poszukiwania. Myślenie to skierowane jest na wykrycie informacji i faktów służących potwierdzeniu lub zaprzeczeniu sądów czy przekonań (Adamek, 1998).

Samo pojęcie myślenia matematycznego związane jest z procesem rozszerzającym pojęcie myślenia. Przejawem myślenia matematycznego jest wykorzystywanie matematyki w codziennym życiu oraz formułowanie swoich sądów opartych na rozumowaniu matematycznym, a także na rozwiązywaniu problemów (Ludwikowska, 2017). Myślenie matematyczne rozumiane właśnie jako umiejętność wykorzystywania podstawowych narzędzi matematyki w praktyce powinno stać się główną umiejętnościa, zdobywaną przez każdego ucznia na poszczególnych etapach edukacyjnych, ale przede wszystkim na etapie kształcenia w szkole podstawowej. Dzięki takiemu myśleniu uczniowie mają możliwość poznania świata zewnętrznego od strony ilościowej za pomocą liczb oraz od 
strony formy za pomocą wyobrażeń przestrzennych z wykorzystaniem umiejętności analitycznych i geometrycznych (Neapolitański, 1958). Ponadto istotną rolę w edukacji, głównie edukacji matematycznej, odgrywa myślenie logiczne rozumiane jako zdolność rozumowania oraz integrowania informacji. Ten rodzaj myślenia pozwala nie tylko rozumieć czytany tekst np. książki, ale pozwala także na rozwiązywanie zadań matematycznych, które wymagają abstrakcyjnego pojmowania rozważanych treści. W uczeniu matematyki nieodzowne i niezbędne są umiejętności kojarzenia, uzasadniania, wyciągania wniosków, znajdowania analogii oraz wyciąganie wniosków. W obowiązującej obecnie podstawie programowej za jeden z celów kształcenia matematycznego uznano właśnie umiejętność myślenia logicznego (rozumowania).

\section{Metodologia}

\section{Osoby badane i procedura badania}

Wśród uczniów rozpoczynających naukę w klasie IV na terenie miasta Częstochowy i powiatu częstochowskiego zostało przeprowadzone badanie $\mathrm{w}$ zakresie logicznego myślenia. Celem badania było sprawdzenie poziomu logicznego myślenia uczniów, którzy ukończyli pierwszy etap edukacyjny. Pierwsza część badania przeprowadzona w 2018 i 2019 roku obejmowała metodę sondażu diagnostycznego, technikę ankiety.

\section{Narzędzia badawcze}

Jako narzędzia użyto testu. Składał się on z 10 zadań zamkniętych, jednokrotnego wyboru. Zadania obejmowały treści matematyczne, praktyczne, analizę sytuacji i treści językowe. Za poprawną odpowiedź uczestnik testu otrzymywał jeden punkt, a za złą odpowiedź lub jej brak zero punktów. Uzyskane wyniki poddane zostały weryfikacji w drugiej części badania, w której zadania zamknięte zostały przeformułowane do postaci zadań otwartych. Uczniowie po dokonaniu analizy zadania i rozwiązaniu go musieli samodzielnie podać odpowiedź.

\section{WYNIKI BADAŃ}

Jak pokazuje rysunek 1 najłatwiejszym zadaniem zamkniętym okazało się zadanie 8, które brzmiało: Która spośród wymienionych liter nie wystęuje w nazwie żadnego dnia tygodnia?
A) $\mathrm{W}$
B) C
C) $\mathrm{M}$
D) $\mathrm{T}$

Poprawną odpowiedź zaznaczyło 275 uczniów spośród 321 badanych. Natomiast najtrudniejszym okazało się zadanie 9 , w którym poprawnych odpowiedzi było tylko 46: W pewnej rodzinie jest 3 braci. Każdy z nich ma siostrę. Ile dzieci jest w rodzinie?
A) 4
B) 6
C) 7
D) 5

Jak zaprezentowano na rysunku 2 najłatwiejszym zadaniem otwartym okazało się zadanie 2. Brzmiało ono następująco: Ola i Ala dostały 7zł. Chca je podzielić w ten sposób, aby Ola dostała dokładnie o jedna złotórwkę więcej niż Ala. Ile pieniędzy dostanie Ala? Poprawnej odpowiedzi na to pytanie udzieliło 32 uczniów, a tylko 2 błędnej. Najtrudniejszym zadaniem okazało się $\mathrm{w}$ przypadku zadania otwartego zadanie 5: Zeszyt do matematyki liczy 16 stron. Ile potrzeba cyfr, aby ponumerować każda ze stron zeszytu? Poprawną odpowiedź podało tylko 10 osób spośród 34 badanych. 


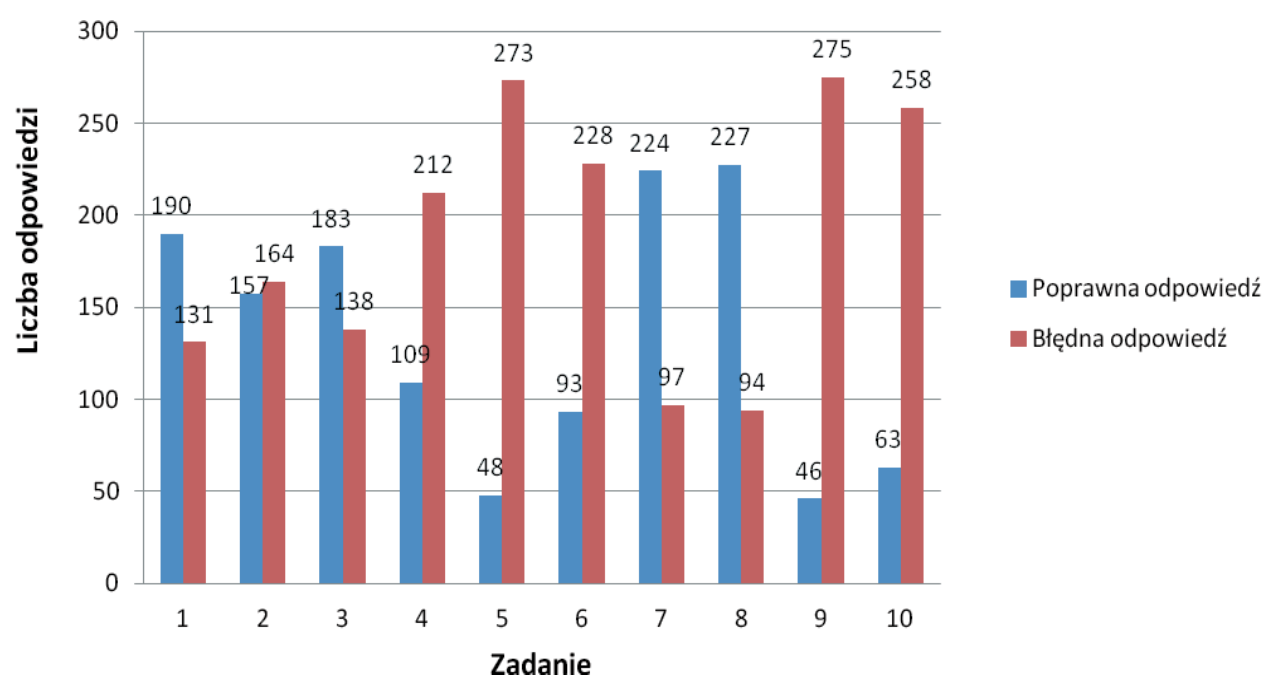

Rysunek 1. Odpowiedzi udzielone w zadaniach zamkniętych. Źródło: Opracowanie własne.

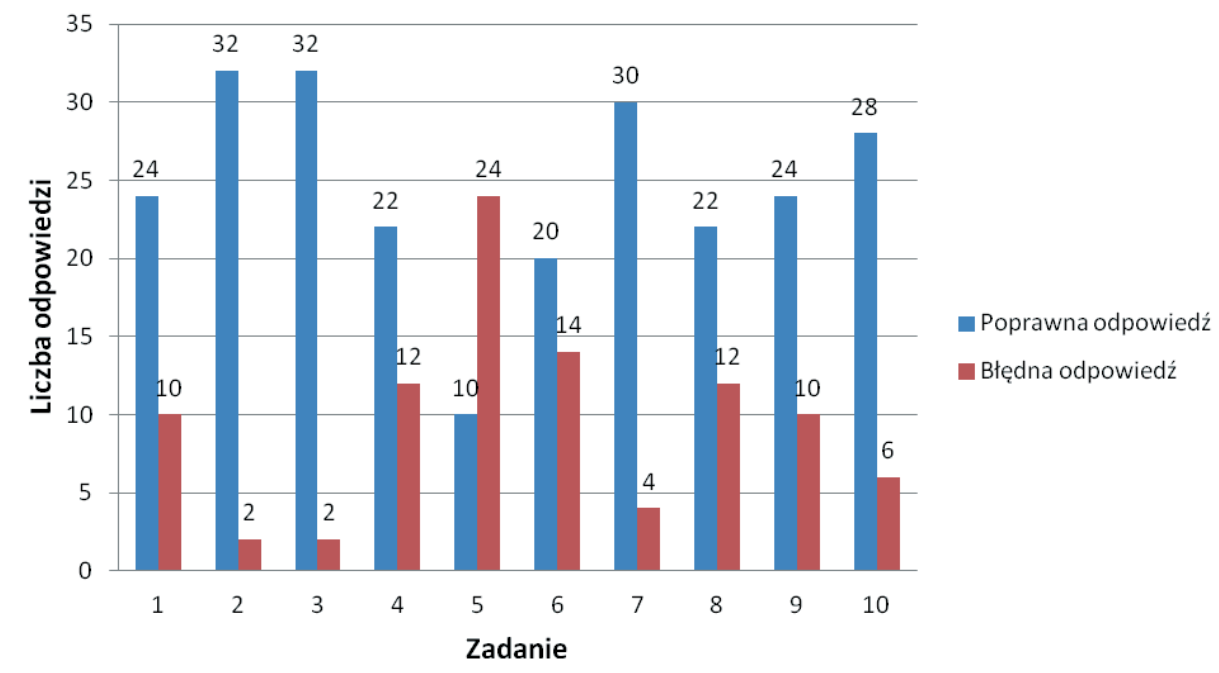

Rysunek 2. Odpowiedzi udzielone w zadaniach otwartych. Źródło: Opracowanie własne. 


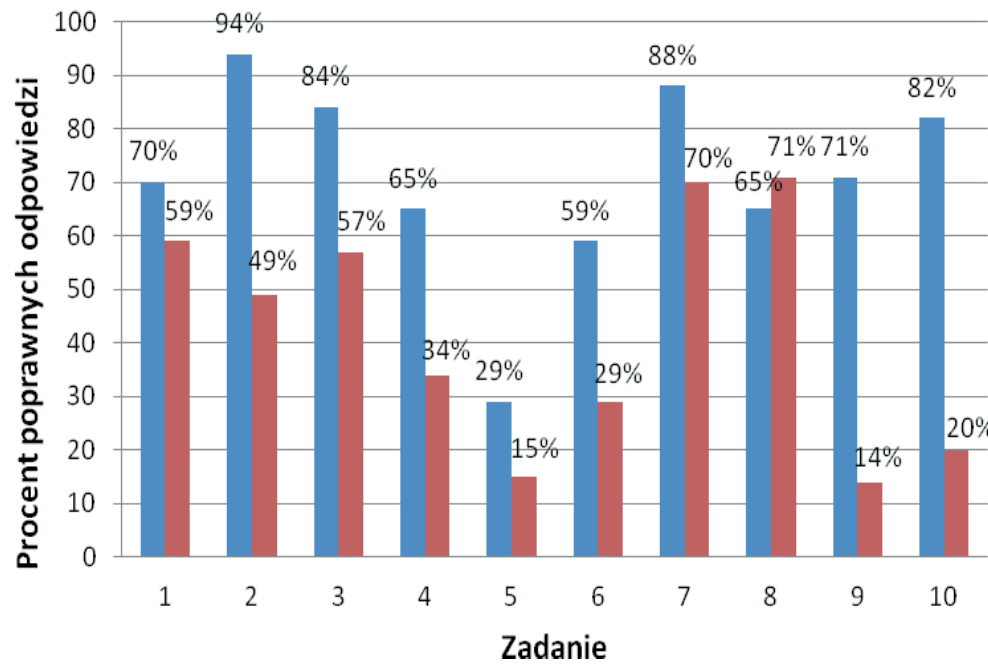

Zadania otwarte

Zadania zamknięte

Rysunek 3. Porównanie odpowiedzi w zadaniach otwartych i zamkniętych. Źródło: Opracowanie własne.

Jak pokazuję rysunek 3 zauważalna jest tendencja sugerująca, że zadania $\mathrm{w}$ formie otwartej były dla uczniów łatwiejsze. W odniesieniu do wszystkich 10 zadań zdecydowanie więcej poprawnych odpowiedzi uczniowie udzielili podczas rozwiązywania zadań otwartych. Największa rozbieżność widoczna jest w zadaniu 10. Dominik ma 3 klawiatury różnego koloru (szara, czarna i biała) oraz 2 myszki (czerwona i niebieska). Ile różnych kolorystycznie zestawów składajacych się z klawiatury i myszki Dominik może złożyć $z$ tych przedmiotów? Różnica $\mathrm{w}$ udzieleniu poprawnej odpowiedzi w zadaniu zamkniętym, a wskazaniu poprawnej w zadaniu zamkniętym, wynosi 62 punkty procentowe. $\mathrm{W}$ zadaniu otwartym uczniowie wizualizowali dane zadania i głównie w graficzny sposób je rozwiązywali. Wypisywali wszystkie kombinacje kolorystyczne ustalenia zestawu klawiatury i myszki. Poniżej kilka przykładowych rozwiązań:

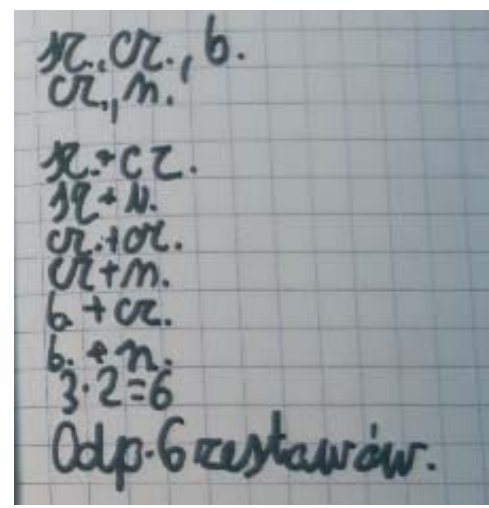

Rysunek 4. Skan pracy ucznia A.

Źródło: własne 


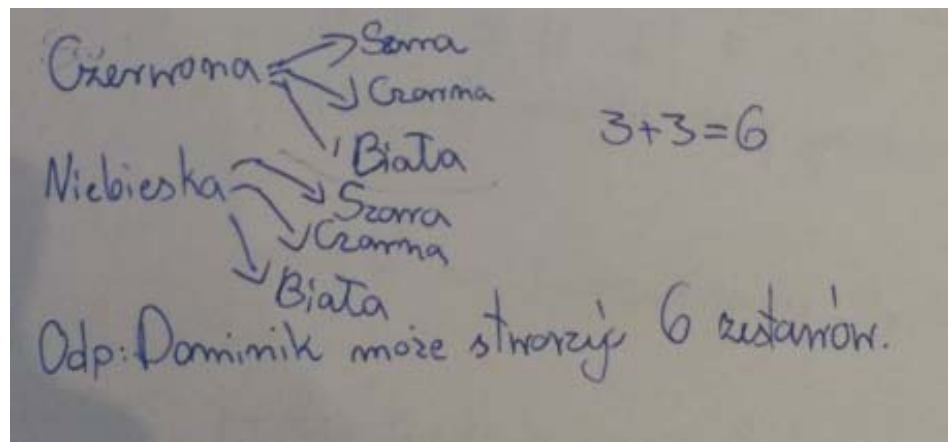

Rysunek 5. Skan pracy ucznia B.

Źródło: własne

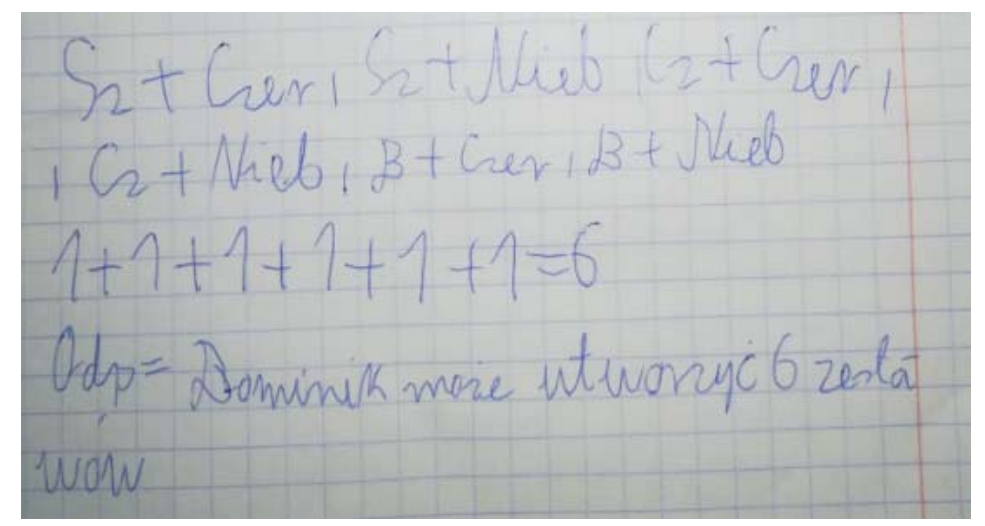

Rysunek 6. Skan pracy ucznia C.

Źródło: własne

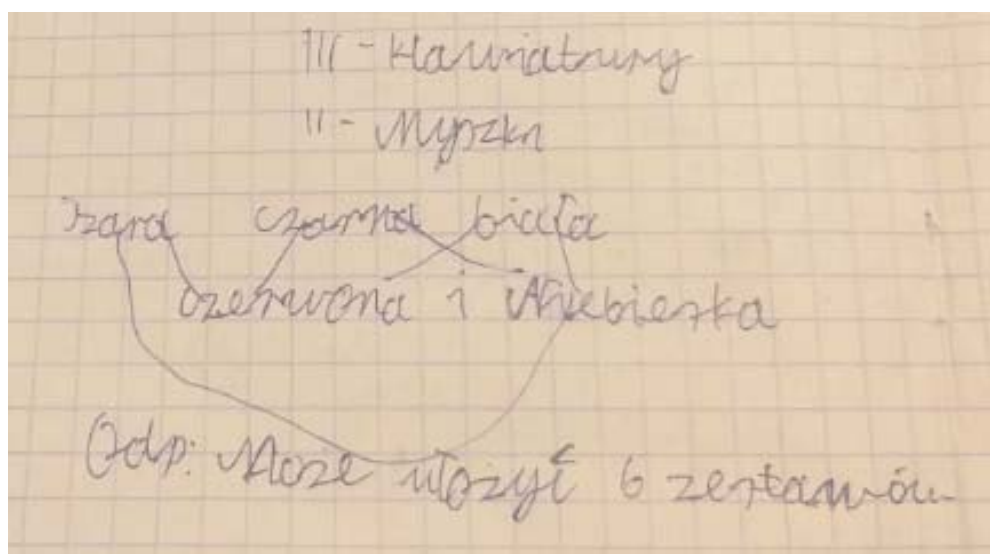

Rysunek 7. Skan pracy ucznia D.

Źródło: własne

Ogrody Nauk i Sztuk nR 2021 (11) 


\section{WNiosKI}

Poziom poprawnego rozwiązania zadań otwartych $(64,3 \%)$ był wyższy niż w przypadku zadań zamkniętych (41,8\%). Różnice te mogą wynikać z tego, że gdy uczniowie mieli do wyboru gotowe odpowiedzi, nie dokonywali ani analizy zadania, ani próby jego rozwiązania. W zadaniach otwartych uczniowie często wizualizowali zawarte $\mathrm{w}$ treści informacje i poszukiwali graficznie poprawnego rozwiązania. Analizując wyniki zadań zamkniętych można stwierdzić, że poziom logicznego myślenia uczniów, którzy ukończyli pierwszy etap edukacyjny nie jest zadowalający. Forma testu zamkniętego nie pozwala jednak na określenie sposobu i metody rozwiązania danego zadania. Uwaga uczniów skupia się na wyborze poprawnej odpowiedzi, a nie na samym rozwiązaniu zadania. Poziom logicznego myślenia w zadaniach, w których uczeń sam poszukiwał odpowiedzi, jest zadowalający. Brak gotowych odpowiedzi zmusza badanych do podjęcia próby analizy zadania i ustalenia metody rozwiązania. Taka forma zadań pozwala na prześledzenie toku myślenia oraz poprawności sposobu rozwiązania zadania. Dzięki temu nauczyciel może podać informację zwrotną uczniowi dotyczącą logiczności rozwiązania oraz wskazać popełnione błędy.

\section{ZAKońCZenIE}

Myślenie matematyczno-logiczne to sposób postrzegania problemów, rozumowania oraz poszukiwania charakterystycznych dróg rozwiązań. Matematyka jako przedmiot szkolny towarzyszący uczniom na każdym etapie edukacji pozwala na rozwijanie myślenia matematycznego, logicznego, kreatywnego i graficznego. Podczas sprawdzania wiedzy i umiejętności uczniów po każdym etapie edukacyjnym należy kłaść większy nacisk na rozwiązywanie zadań otwartych. Takie zadania umożliwiają uczniom rozwój kreatywnego i indywidualnego podejścia do rozwiązania problemu i sprawdzenie przyrostu ich wiedzy i umiejętności. Z przeprowadzonych badań wynika, iż osiągnięcia matematyczne uczniów zależą od poziomu sprawności umysłowej, a głównie od umiejętności logicznego myślenia. Duży wpływ na osiągane rezultaty ma również forma dobieranych zadań sprawdzających.

Dla większości uczniów matematyka jest wyzwaniem, ponieważ wymaga rzetelności, umiejętności analizowania, dochodzenia do wniosków i przede wszystkim logicznego myślenia.

\section{Bibliografia}

[1] Adamek, I. (1998). Rozziazywanie problemów przez dzieci. Kraków: Wydawnictwo Oficyna Wydawnicza IMPULS.

[2] Bonar, J. (2013). O potrzebie rozwijania myślenia twórczego w edukacji matematycznej uczniów. W: A. Kalinowska (red.), Wczesnoszkolna edukacja matematyczna - ograniczenia i ich przełamywanie. (ss. 79-92). Olsztyn: Wydawnictwo Uniwersytetu Warmińsko-Mazurskiego.

[3] Gębuś, D., Pierzchała, A. (2016). Twoórczy nauczyciele, pomystowi uczniowie: osobowościowe korelaty kreatyzności nauczycieli w perspektywie analizy transakcyjnej. Częstochowa: Wydawnictwo Akademii im. Jana Długosza w Częstochowie.

[4] Ludwikowska, E. (2017). Myślenie matematyczne uczniów szkół ponadgimnazjalnych na przykładzie uczniów województwa kujawsko-pomorskiego. W: B. Niemierko, M. K. Szmigiel, (red.), Diagnozowanie umiejętności praktycznych w toku kształcenia i egzaminowania. Kraków: Wydawnictwo Grupa Tomami, Polskie Towarzystwo Diagnostyki Edukacyjnej

[5] Neapolitański, S. (1958). Zarys dydaktyki matematyki. Warszawa: Wydawnictwo Państwowe Zakłady Wydawnictw Szkolnych.

[6] Pólya, G. (1976). Odkrycie matematyczne. Warszawa: Wydawnictwo Naukowo - Techniczne 